\title{
Cueing Hierarchy Is an Effective Language Stimulator Treatment Technique of Language Disorder for Patients with Anomic Aphasia
}

\author{
Nurvin Jahan Asha ${ }^{a}$ Mohammad Kamrujjaman ${ }^{b}$ \\ a Department of Speech and Language Therapy, Centre for Rehabilitation of the Paralysed (CRP), Dhaka,

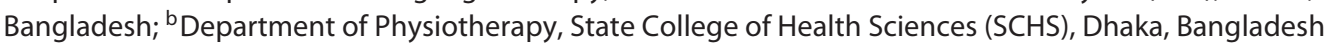

\author{
Keywords \\ Cueing hierarchy - Treatment technique . \\ Language disorder . Anomic aphasia
}

\begin{abstract}
Background: Stroke and degenerative disease are the cause of anomic aphasia. In this condition, expressive language is affected. Cueing hierarchy $(\mathrm{CH})$ is one of the treatment approaches used to improve the expressive language of naming or efficiency in word retrieval of patients with anomic aphasia. Purpose: In this study, the investigators tried to find out how and what type of changes would occur in the word retrieval (noun) of patients with anomic aphasia using $\mathrm{CH}$. Methods: This study was conducted using a pre-experimental study design. Ten samples were selected by purposive sampling from the Centre for the Rehabilitation of the Paralysed (CRP), Savar and Mirpur, Dhaka, Bangladesh. Results: Before and after the test, the patients were assessed by the BNT (Boston Naming Test) translated in Bangla as a data collection tool and were administered 16 sessions for therapy. The result was analyzed by the inferential statistical parametric related $t$ test. The result of the participants' changes was significant in naming performance $(p=0.006<0.05)$. Conclusion: It is concluded
\end{abstract}

\begin{tabular}{ll}
\hline KARGER & $\begin{array}{l}\text { (c) } 2019 \text { The Author(s) } \\
\text { Published by S. Karger AG, Basel }\end{array}$ \\
E-Mail karger@karger.com & This article is licensed under the Creative Commons Attribution- \\
www.karger.com/dmj & $\begin{array}{l}\text { NonCommercial-NoDerivatives 4.0 International License (CC BY- } \\
\text { NC-ND) (http://www.karger.com/Services/OpenAccessLicense). } \\
\text { Usage and distribution for commercial purposes as well as any dis- } \\
\text { tribution of modified material requires written permission. }\end{array}$
\end{tabular}

that $\mathrm{CH}$ is effective for patients with anomic aphasia. Further study analyzing different settings and patients from all socioeconomic backgrounds and geographic areas of Bangladesh is warranted.

(C) 2019 The Author(s)

Published by S. Karger AG, Basel

\section{Introduction}

Language is a means to communicate with others. Language impairment has a devastating impact on the quality of life as it contributes to a high level of long-term disability. One of the most devastating language disabilities is aphasia, which is an obstacle to communicate [1]. Aphasia is a disorder that results from damage to portions of the brain that are responsible for language. For most people, these are areas on the left hemisphere of the brain [2]. The disorder impairs the expression and understanding of language as well as reading and writing [3]. Anomic aphasia is a naming disorder that may be conspicuous in spontaneous or conversational speech. Naming disorders as a symptom are always found in patients with aphasia, especially in patients with anomic aphasia. Patients with anomic aphasia 
Table 1. Demographic data of the participants $(n=10)$

\begin{tabular}{|c|c|c|c|c|c|c|c|}
\hline Subject & $\begin{array}{l}\text { Age, } \\
\text { years }\end{array}$ & $\begin{array}{l}\text { Educational } \\
\text { background }\end{array}$ & $\begin{array}{l}\text { Post-onset } \\
\text { of CVA, } \\
\text { months }\end{array}$ & Occupation & Etiology & $\begin{array}{l}\text { Types of } \\
\text { aphasia }\end{array}$ & Institution \\
\hline P 1 & 54 & literate & 19 & govt. employee & CVA & anomic & CRP, Savar \\
\hline P 2 & 34 & literate & 16 & businessman & CVA & anomic & CRP, Savar \\
\hline P 3 & 38 & literate & 4 & $\begin{array}{l}\text { non-govt. } \\
\text { employee }\end{array}$ & CVA & anomic & CRP, Savar \\
\hline P 4 & 50 & literate & 9 & $\begin{array}{l}\text { non-govt. } \\
\text { employee }\end{array}$ & CVA & anomic & CRP, Savar \\
\hline P 5 & 20 & illiterate & 19 & daily worker & CVA & anomic & CRP, Savar \\
\hline P 6 & 50 & literate & 19 & $\begin{array}{l}\text { non-govt. } \\
\text { employee }\end{array}$ & CVA & anomic & CRP, Mirpur \\
\hline P 7 & 45 & literate & 19 & $\begin{array}{l}\text { non-govt. } \\
\text { employee }\end{array}$ & CVA & anomic & CRP, Mirpur \\
\hline P 8 & 36 & literate & 19 & $\begin{array}{l}\text { govt. } \\
\text { employee }\end{array}$ & CVA & anomic & CRP, Mirpur \\
\hline P 9 & 52 & literate & 19 & $\begin{array}{l}\text { govt. } \\
\text { employee }\end{array}$ & CVA & anomic & CRP, Mirpur \\
\hline P 10 & 60 & literate & 6 & $\begin{array}{l}\text { govt. } \\
\text { employee }\end{array}$ & CVA & anomic & CRP, Mirpur \\
\hline
\end{tabular}

P, patient; govt., government; CVA, cardiovascular accident; CRP, Center for Rehabilitation of the Paralysed.

have a clear understanding but cannot articulate and name the target word [4]. There are many intervention programs available to retrieve or name words, and many research papers are devoted to case studies examining treatments for naming difficulties, using a wide range of tasks that address varying levels of impairment $[5,6]$. Intervention is used as the combination of semantic and phonological techniques [7]. In this study, the investigators tried to find out how and what type of improvement would occur in the word retrieval (nouns) of patients with anomic aphasia by use of cueing hierarchy $(\mathrm{CH})$.

\section{Anomic Aphasia: Basic Feature}

Anomic aphasia is an expressive, non-fluent aphasia. It is characterized by word finding difficulties or naming difficulty $[1,8]$. Patients have a clear understanding but difficulty in expression [9]. Patients know the meaning of the words and are able to recognize errors. When making an error, they keep on trying to select the correct word but have limited ability to retrieve phonological information about a word, or cannot articulate it [5].

\section{Cueing Hierarchy}

A cue is a signal that tells the patient how he/she should produce the required response. It may be verbal or nonverbal [10]. There are many cues available for patients
Table 2. Naming performance (single word) of the participants by the paired $t$ test $(n=10)$

\begin{tabular}{lll}
\hline Participants & Pre-test score & Post-test score \\
\hline 1 & 2.35 & 2.48 \\
2 & 0.21 & 0.34 \\
3 & 0.19 & 0.45 \\
4 & 0.13 & 0.29 \\
5 & 0.27 & 0.34 \\
6 & 0.27 & 0.34 \\
7 & 0.07 & 0.07 \\
8 & 0.65 & 0.66 \\
9 & 1.65 & 1.75 \\
10 & 0.37 & 0.37 \\
Mean score & 0.6160 & 0.7090 \\
\hline
\end{tabular}

with anomic aphasia, such as functional cues, description cues, categorical cues, phonemic cues, semantic cues, etc. [11]. However, some studies in the literature show that these cues work more effectively when they maintain a hierarchy [12]. So, in this study, investigators identified $\mathrm{CH}$ as a therapy program for patients with anomic aphasia. $\mathrm{CH}$ consists of the ten levels of hierarchy that are used in this study $[6,13]$. $\mathrm{CH}$ is a treatment program that consists of cues. It helps the patient with anomic aphasia to deal with the naming problem. 
Table 3. Mean of the area of language (naming)

\begin{tabular}{|c|c|c|c|c|c|c|c|}
\hline \multirow{2}{*}{$\begin{array}{l}\text { Objective of } \\
\text { the study }\end{array}$} & \multicolumn{2}{|l|}{ Mean } & \multicolumn{2}{|c|}{$95 \% \mathrm{CI}$ of the difference } & \multirow[t]{2}{*}{$t$ value } & \multirow[t]{2}{*}{ df } & \multirow[t]{2}{*}{$p$ value } \\
\hline & before treatment & after treatment & lower & upper & & & \\
\hline $\begin{array}{l}\text { Naming } \\
\text { performance } \\
\text { of single word } \\
\text { (noun) }\end{array}$ & 0.6160 & 0.7090 & -0.15161 & -0.03439 & -3.590 & 9 & 0.006 \\
\hline
\end{tabular}

The $p$ value is significant $(p=0.006<0.05$ ), indicating that $\mathrm{CH}$ is effective in patients with anomic aphasia for naming a single word.

\section{Materials and Methods}

We conducted a pre-experimental study to analyze 10 male patients with a clinically diagnosed cerebrovascular accident. The investigators tried to understand the effect of $\mathrm{CH}$ for patients with anomic aphasia. The pre- and post-tests were a specific type of pre-experimental research design. It was used in this study because it helped explain what happened following the beginning of the independent variable [14]. Randomization and control groups were absent in this study. The same subject design is a variant of the experimental design, which involved testing of the same group and also provided the intervention program in this study. The subjects are typically used before and after design. In the pre-experimental study design, it is possible to describe phenomena or relationships [15]. The study was conducted in two settings. One setting was the Adult Neurology Unit of the Speech and Language Therapy Department, CRP Savar, and the other one was the Adult Neurology Unit of the Speech and Language Therapy Department, CRP Mirpur. These two settings were used because they are the only specialized centers available for patients with anomic aphasia.

\section{Results}

Table 1 shows that half $(n=5.50 \%)$ of the participants were $\geq 50$ years of age. The youngest age was 20 years, and the oldest age was 60 years. Considering the educational background, most participants were literate, and only 1 participant was illiterate. Regarding the duration of post-onset of cardiovascular accident, about $60 \%(n=$ 6) of the participants had 19 months followed by 16 months $(10 \% ; n=1), 9$ months $(10 \% ; n=1), 6$ months $(10 \% ; n=1)$, and 4 months $(10 \% ; n=1)$, respectively. The majority of participants were government $(n=4,40 \%)$ and non-government employees $(n=4,40 \%)$. The prescore and post-score data were assessed by the Boston Naming Test (BNT), and the mean score of the participants before applying $\mathrm{CH}$ was 0.6160 , and after applying
$\mathrm{CH}$ it was 0.7090 , as shown in Table 2. The data show smaller differences between the scores. The $t$ value was -3.590 , and the $p$ value was $<0.05$, indicating that the study finding is significant for naming performance, as shown in Table 3.

\section{Discussion}

The purpose of this study was to focus on the scenario of naming ability in Bengali patients with anomic aphasia after getting treatment with $\mathrm{CH}$. The aim was to detect the level of improvement among patients. $\mathrm{CH}$ is a combination of different types of cues, such as semantic cues, phonemic cues, and repetition, etc. It has been observed that patients with anomic aphasia show poor naming abilities and symptoms of stroke. So, it affects their ability to express daily needs as well as their personal and social life. The amount of therapy was sufficient in this case. According to Karuppali et al. [12], the organization of language in an individual depends upon various components such as phonology, semantics, syntax-morphology, and pragmatics. Every component has its own relevance in the usage of language. Semantics, forming the content of language, contains nouns and verbs as the core vocabulary for the formulation of language. Studies have been done focusing on the significance of $\mathrm{CH}$ to produce nouns in the patients with anomic aphasia. However, in anomic aphasia, the retrieval of target words or naming impairment is indicated as word nouns. Mainly nouns are affected. According to Nettleton and Lesser [16], three of the subjects receiving model-appropriate therapy showed improved naming ability after 8 weeks of therapy. The results suggest that applying a processing model in selecting patients for therapy for naming difficulties is a promising development. The efficacy of using cues to elicit an easy retrieval 
of a target word has been the focus in many studies [17]. The cues to be included in a therapy program will depend upon their effect on the patient and will be generalized to all communicative environments.

\section{Conclusion}

It is concluded that there was a significant difference between the mean improvement scores for the sample, indicating that $\mathrm{CH}$ is an effective language stimulator treatment of language disorder for anomic aphasia patients. This study was only conducted in the CRP setting. So, it is recommended to do further study in different settings, including patients from all socioeconomic backgrounds and geographic areas of Bangladesh.

\section{Acknowledgement}

The authors would like to thank all participants and also acknowledge the support provided by the Department of Speech and Language Therapy at Bangladesh Health Professional Institute (BHPI), Savar, and the State College of Health Sciences (SCHS), Dhaka, Bangladesh.

\section{Statement of Ethics}

The authors of the article declare that there are no ethical conflicts regarding this article.

\section{Disclosure Statement}

Organizations or entities with a direct financial attention on the subject matter or materials discussed in the study were not involved, and the authors declare that they have no conflicts of interest to disclose.

\section{References}

1 Love RJ, Webb WG. Neurology for the Speech-Language Pathologist. 4th ed. New Delhi: Butterworth- Heinemann; 2001.

2 Helm-Estabrooks N, Albert ML. Manual of Aphasia and Aphasia Therapy. 2nd ed. USA: Pro.ed; 2003.

3 Chapey R. Language Intervention Strategies in Adult Aphasia. USA: Library of Congress; 1994.

4 Lorwatanapongsa P. Naming disorders anomic aphasia. J Med Assoc Thai. 2005 Sep;88(4 Suppl 4):S369-72. Available from: http:// www.mat.or.th/journal/files/Vol88_No4_ 369.pdf.

5 Whitworth A, Webster J, Howard D. (2005). A Cognitive Neuropsychological Approach to Assessment and Intervention In Aphasia. New York: Psychology Press; 2013.

6 Linebaugh CW, Lehner LH. Cueing hierarchies and word retrieval: A therapy program. Proceedings of the conference on clinical Aphasiology. 1977. Available online: http://aphasiology. pitt.edu/archive/00000622/01/07-04.pdf.
7 Nicholas LE, Brookshire RH, MacLennan DL, Schumacher JG, Porrazzo SA. (2012) Boston Naming Test: Revised Administration and Scoring Procedures and Normative Information for Non-Brain-Damaged Adults. Available online: http://aphasiology.pitt.edu/archive/00000069/01/18-10.pdf.

8 Tenner DC. Exploring Communication Disorders: A 21st Century Introduction through Literature and Media. USA: Library of Congress; 2003.

9 Shipley KG, McAfee JG. Assessment in Speech-Language Pathology: A Resource Manual (3rd ed). United States: Thomson Delmar Learning; 2004.

10 Paul R. Introduction to Clinical Methods in Communication Disorders. London: Brookes Publishing Co.; 2002.

11 Attrill C, Bolster L, McDonald H, O'Leary I. Sourcebook for Student Placements: A Resource for Speech \& Language Therapists. Northumberland: Stass Publications; 2008.

12 Karuppali S, Samaraweera B, Premalatha BS. Cueing Hierarchy as an Effective Treatment Approach in the Treatment of Anomic Aphasia, Language in India. 11.336-345. 2011.
13 Wambaugh J. A comparison of the relative effects of phonologic and semantic cueing treatments. Aphasiology. 2003; 17(5):433-41. Available from: http://www.tandfonline.com/ page/terms-and-conditions.

14 BAILEY DM. RESEARCH FOR THE HEALTH PROFESSIONAL: A PRACTICAL GUIDE (2ND ED). PHILADELPHIA: F.A. DAVIS COMPANY; 1997.

15 Hicks CM. RESEARCH METHODS FOR CLINICAL THERAPISTS: APPLIED PROJECT DESIGN AND ANALYSIS (3RD ED). EDINBURGH: CHURCHILL LIVINGSTONE; 1999.

16 Nettleton J, Lesser R. Therapy for naming difficulties in aphasia: application of a cognitive neuropsychological model. J Neurolinguist. 1991;6(2):139-57.

17 Coelho CA, McHugh RE, Boyle M. Semantic feature analysis as a treatment for aphasic dysnomia: A replication. Aphasiology. 2000; 14(2):133-42. 